\title{
The Utilization of Rattan Slice Industrial Waste as Rattan Fiber Ropes and Its Application in Furniture Design
}

\author{
Sumarno* \\ Design Department, Faculty of Fine Arts and Design, Indonesian Institute of the Arts, Surakarta, Indonesia \\ Andi Tantra Tellu \\ Biology study program, Faculty of Teacher Training and Education, Tadulako University, \\ City of Palu, Central Sulawesi, Indonesia \\ Agung Cahyana \\ Craft Department, Faculty of Fine Arts and Design, Indonesian Institute of the Arts, Surakarta, Indonesia
}

The research is financed by Kemenristek DIKTI.

\begin{abstract}
Rattan processing in the handicraft and furniture industry generates an abundant amount of residual production waste. One of the stages causing lots of waste is the splitting stage. For this reason, this study aims to expose a process of how the rattan waste from the splitting stage into rattan fiber ropes. The research was conducted using an applied research method, in which the rattan fiber ropes are applied into furniture products. The research was carried out through several stages including: preparing, soaking, washing, pressing, drying, twisting and testing the ropes on some application in furniture design.Soaking process is to make the rattan slices softer, before being pressed to break the bonds between the fibers to make them more flexible. Efforts to produce rattan fiber rope are carried out by twisting and intertwining. The product result, rattan fiber rope, is a semi-finished alternative material for the handicraft and furniture industry. The utilization of rattan fiber ropes is for environmentally friendly furniture designs, through the implementation of stacking system to overcome any hindrance including high transportation cost (fried ocean) for rattan industry players.
\end{abstract}

Keywords: rattan, waste, design, furniture.

DOI: $10.7176 / \mathrm{ADS} / 98-03$

Publication date: January $31^{\text {st }} 2022$

\section{Introduction.}

Rattan is the most important non-timber forest product commodity for industrial purposes. In Indonesia, rattan is widely used for any purposes in the handicraft and furniture industry. $80 \%$ of rattan material is for the furniture industry, while the handicraft industry needs $17 \%$ of it, and $3 \%$ is for other industries (Anonim, n.d.). The products made by the handicraft and furniture industry include chairs, tables, frames, boxes, baskets etc. The rattan processing into handicrafts and furniture products, however, meets challenges, especially related to production efficiency. (Zuraida, Maisarah, and Wan-Shazlin-Maisarah 2017) the number of industrial inefficiency is very high, that is reaching $50 \%$.

Splitting is one of the stages of the production process in the rattan industry which generates the most waste (Januminro, CFM, n.d.). This process is to produce semi-finished materials in the form of rattan skin split, rattan split and rattan core (fitrit). The splitting process generates waste in the forms of elongated rattan slices, with unstable or inconsistent cross-sectional shapes, sizes, and thicknesses. The slices by the industry players are therefore categorized as waste. Rattan slices production waste usually ends up burned because they are considered having no useful value. One of the examples is CV. Sumber Rejeki, Sukoharjo, Central Java Indonesia, a company that processes rattan raw materials into semi-finished materials such as: rattan split and rattan cores, each day produces $100-150 \mathrm{~kg}$ of rattan slice waste. This abundant amount of waste, therefore, needs some efficiency efforts in its management or utilization, for instance, by using them as rattan fiber ropes.

Some studies related to natural fibers have also been undertaken. Natural fiber materials other than rattan which are used as rope materials include hemp, sisal, kenaf, pineapple leaves, and rice straw (Sumarno, Dharsono, and Chandra 2020). Previous research have explored several study focuses such as: some optimizations of natural fibers, the treatments of rattan canes cut into fibers, and rattan powder (Steven, Mardiyati, and Suratman, n.d.); and strands of rattan fiber (Sahoo et al. 2019). Another study is about bamboo that is cut into short pieces to become bamboo fibers after going through several stages (Zakikhani et al., n.d.). Kenaf plants also have been studied as strands of fiber for rope making (Edeerozey et al., n.d.). Finally, this research adds the list of explorations regarding the efforts to efficiently utilize waste, especially from rattan production, to be an alternative material for furniture design purposes. 


\section{Material}

The material of this research is the rattan slices from rattan industrial waste. The slices are the elongated rattan core waste with irregular cross sections and inconsistent thickness. The rattan slices in this study were taken from CV. Sumber Rejeki, one of the rattan furniture industry centers in Sukoharjo, Central Java, Indonesia. Since they are usually burned, the abundant amounts of slices were given for free. Besides, the tools needed for this study were a soaking tub and a roller pressing machine to squeeze and separate the rattan fibers.

\section{Methods}

This research was carried out with an applied research approach regarding ropes for furniture products, involving rattan fiber rope as primary concern. Therefore, as the research material, the rattan slices were not cut, they were left lengthwise. The research process is carried out through the following stages:

a) Research preparation, involves collecting rattan slices as waste material from rattan processing industry, water, also several equipment including soaking tubs, roller press machines, micrometers, and drying boards.

b) The rattan slices then are soaked in water.

c) Pressing to release the rattan fiber bonds to make it more flexible, and to squeeze out the water contained in the rattan slices.

d) Drying.

e) Twisting the rattan slices which is followed by intertwining process.

f) Designing furniture to utilize rattan fiber rope.

g) Prototype making.

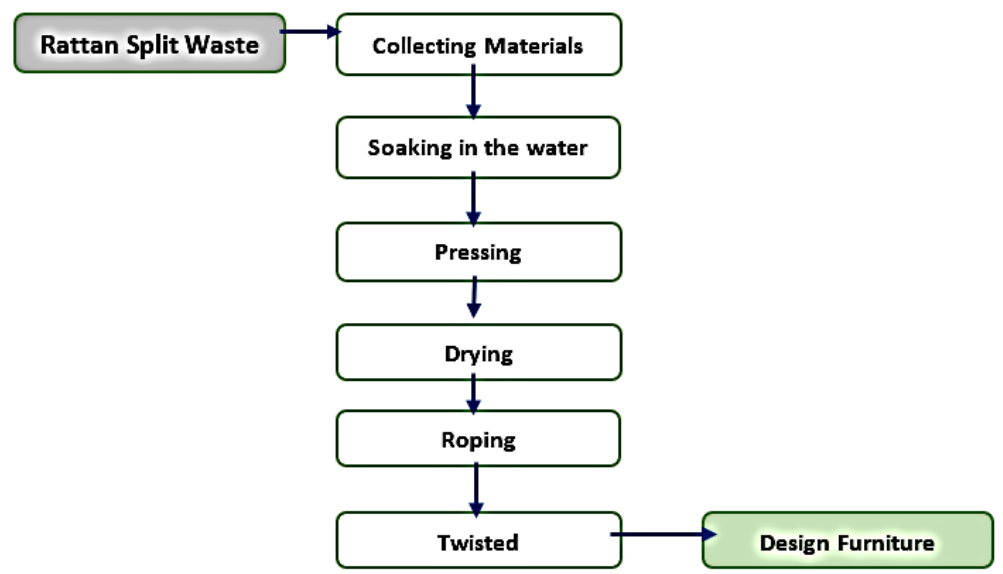

Figure 1: The Research Scheme.

\section{Result}

Rattan slices as waste from the splitting process in the rattan industry are generally left to pile up and then burned. The efforts regarding waste management and utilization require collecting, arranging and binding them into elongated bundles are to facilitate soaking process.

In the next process, the rattan slices are to be soaked for 4 days to soften. The softer material is then pressed using a roller press. The roller press works by pressing and rotating so that it can squeeze water and dissolve non-cellulose substances. The result is in the forms of strands of elongated rattan fibers that are still fused to one another and in a semi-dry condition. The half dry material can completely dry only by airing, without any mechanical drying tool.

The rattan slices that have been soaked and pressed to make ropes are then twisted. Two or three twists are then joined together by intertwining them to become a rattan fiber rope. The technique of making ropes, based on the number of the twists, is generally categorized into 2 twists and 3 twists. Ropes made of rattan slices with 2 twists on average produces ropes with an average diameter of 3-4 mm. Meanwhile, 3-twist ropes usually produce ropes with diameter of $5-7 \mathrm{~mm}$. However, most commonly, the ropes made from mendong, straw, sea grass, and banana midrib for the handicraft and furniture industry were two-twist type. This is due to considerations of effectiveness and efficiency related to the process of rope-making.

Rattan fiber ropes made with 2 twists are quite strong, dense, flexible, also having distinctive texture and a natural light brown color. Its tensile strength is also not inferior compared to other ropes made of natural fiber materials. The fiber ropes from rattan are even stronger than those made of mendong, palm fiber, rice straw, banana midrib, and loom. The density of rattan fiber ropes is also better compared to the ropes made of banana stem fiber, water hyacinth, or coconut fiber. 
Even though the texture is smoother than the ropes made of natural fibers such as palm fiber, coconut fiber or straw rope, rattan fiber ropes are coarser than those made from other natural fibers such as mendong, sea grass, hemp fiber, or kenaf fiber.

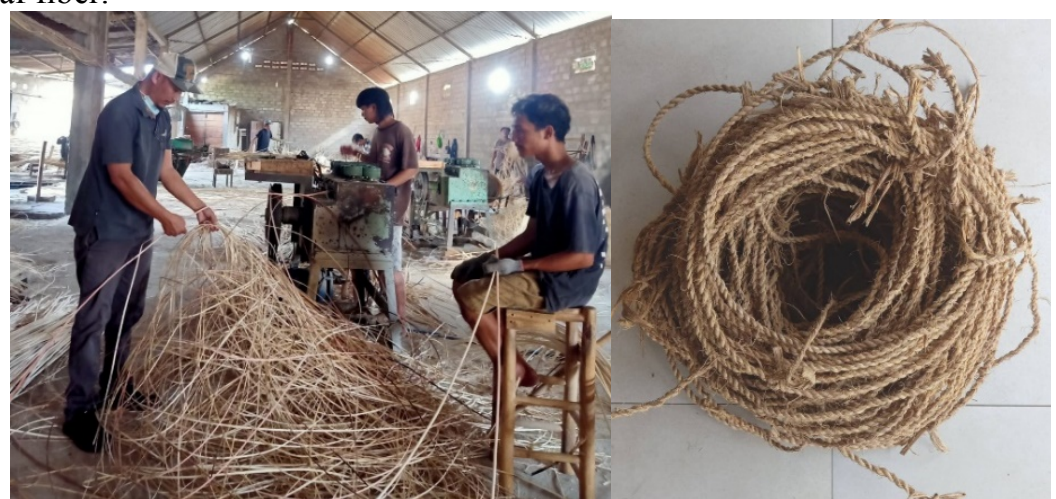

Figure 2: the slices (rattan industrial waste) and experimental rattan fiber ropes

The handicraft and furniture industry in Indonesia uses natural fibers to make products. The most commonly used techniques are weaving and binding. The development of environmentally friendly products through the application of rattan fiber rope as a residual production waste is interesting to pursue.

Rattan fiber rope is classified as quite new material. In its development, a rattan fiber-based furniture design begins with a bench. The initial stage is the process of adjustment, also extracting knowledge, skills and experience. Therefore, the application of weaving patterns and binding techniques is still quite simple. The weaving pattern applied is straight weaving with a braid pattern, with the clove knots technique.

The COVID-19 pandemic brought an impact on activities and production covering various aspects, including the handicraft and furniture industry. The high cost of transportation (fried ocean) is one of the impacts felt by the handicraft and furniture industry, especially for foreign markets. A set of system, known as knocking down, folding, and stacking may help transportation efficiency, therefore, is interesting to apply as a solution (Marizar, Irawan, and Beng 2019).

Stacking is a system that is possible to apply with the least technical risk compared to knocking down and folding systems. The use of rattan fiber ropes with 2 twists was chosen because the size is not too big so that for the manufacture of some products it still looks neat. The images below are the sketches, 3D drawings and prototypes of the bench which applies rattan fiber rope.

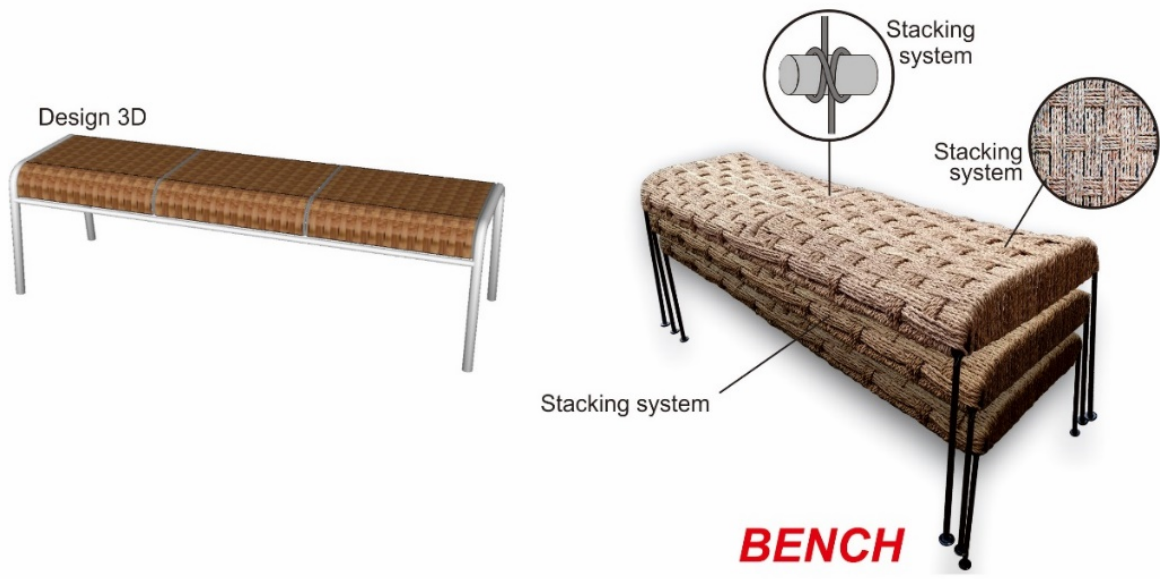

Figure 3: Bench design with stacking system using rattan fiber rope.

\section{Discussion}

Rattan is basically a natural material that can be used for various purposes (Dransfield and Manokaran 1993). Containing high fiber, rattan is a natural material that can be used for various human purposes. Utilization by optimizing rattan fiber for rope making, however, is still very minimal. This is because rattan as a non-timber forest product commodity is oriented towards rattan stems, rattan skin, and rattan core.

Natural fiber-producing plants that are used for making ropes include sisal, kenaf, hemp, mendong, coconut fiber, bamboo and other materials. Rattan slices as waste in the rattan furniture and handicraft industry have not been processed and used much, even they usually end up burned. This condition occurs in several industrial centers for handicrafts and rattan furniture in Cirebon, Sukoharjo, Jepara and Surabaya. The utilization of rattan slices as waste from the remaining fibers into rope is an effort to increase both added value and economic value. 
Soaking into water, steaming, and heating rattan material with a rattan blowtorch are common efforts made by craftsmen in the rattan industry to make rattan more flexible, and not easily broken. Bending, twisting, weaving are the most dominant work processes. Additionally, due to the need of high flexibility material for rope making, it is therefore necessary to conduct a process of pressing.

Twisting and intertwining are the most important stages of utilizing rattan slices to make ropes. This is because the production cost for making ropes manually is the biggest cost. The amount or quantity produced and the quality including the consistency of density and diameter of the ropes are largely determined at the twisting and intertwining stages. The entire stages of processing rattan slices into rattan ropes are zero waste (not generating any solid waste).

The twisted and intertwined rattan slices into rattan fiber ropes allow unequal density and diameter. The difference in size occurs because the slice sizes as rattan waste are not the same from one another. Another problem with some slices is the thickness of the poles of one another is not the same, too. Rattan fiber rope has a higher tensile strength compared to natural fiber ropes made of water hyacinth, coconut fiber, banana stems, and rice straw ropes, the natural fiber ropes which are also used for craft products and furniture.

The fiber surface of rattan rope is however not smoother than that of mendong, hemp, kenaf, and banana stems. Therefore, to consider the position or placement of the application of rattan fiber rope for furniture products is very important. The bench was selected as a starting point for furniture design in the context of utilizing rattan fiber rope because bench is a furniture product with low complexity.

Braiding, weaving and knotting are the most common working techniques used in the rattan furniture craft industry. The weaving technique of gedekan pattern is the simplest pattern. The gedekan is a typical Javanese bamboo strands weaving work, widely used for house walls by traditional people and even still exists today in the handicraft and furniture industry (Jasper and Pirngadie 1912). Knots are perfect for weaving work; therefore, there are various knot techniques in the rattan craft and furniture industry. The application of the clove knot technique is the simplest technique (Kurniasih 2008). This is then adopted to support the productivity of the rattan handicraft and furniture industry through the effectiveness and efficiency of materials and production processes.

\section{Conclusion}

The utilization of rattan slices to make rattan fiber rope is an effort to increase efficiency and the economic value of residual production waste. Rattan fiber rope can thus be used as an alternative material for the development of handicraft and furniture products. However, the effectiveness, efficiency, and utilization need to be studied for further research. In addition, any methods for equalizing the size of rattan slices and mechanical rope-making are recommended to pursue for the sake of effectiveness, efficiency, quality and quantity of ropes as semi-finished materials for handicraft and furniture products. In relation to the utilization of rattan fiber rope, it is necessary to continue to develop designs with various working techniques for any categories of product types.

\section{References}

Anonim. n.d. Indonesia's Remarkable Rattan. Kementerian Perdagangan $\{\mathrm{RI}\}$.

Dransfield, John, and N Manokaran. 1993. Rattans, Plant Resources of Southeast Asia 6. Bogor: PROSEA.

Edeerozey, A M Mohd, Hazizan Md Akil, A B Azhar, and M I Zainal Ariffin. n.d. "Chemical Modification of Kenaf Fibers" 61: 2023-25. https://doi.org/10.1016/j.matlet.2006.08.006.

Januminro, CFM. n.d. Rotan Indonesia: Potensi, Budi Daya, Pemungutan, Pengelolaan, Standar Mutu Dan Prospek Pengusaha. 6th ed. Kanisius.

Jasper, J.E, and Mas Pirngadie. 1912. De Inlandsche Kunstnijverheid in Nederlandsch Indie I. Het Vlechtwerk. Van Regeeeringswegw Gedruk: Mouton \& Co.

Kurniasih. 2008. Aneka Kerajinan Tali. Bandung: Karya Kita.

Marizar, Eddy Supriyatna, Agustinus Purna Irawan, and Jap Tji Beng. 2019. "The Knock down System of Rattan Furniture for Global Market." IOP Conference Series: Materials Science and Engineering 508 (1). https://doi.org/10.1088/1757-899X/508/1/012104.

Sahoo, Sunil Kumar, Jyoti Ranjan Mohanty, Subhakanta Nayak, and Bibhudatta Behera. 2019. "Chemical Treatment on Rattan Fibers: Durability, Mechanical, Thermal, and Morphological Properties." Journal of Natural Fibers. https://doi.org/10.1080/15440478.2019.1697995.

Steven, Mardiyati, and R Suratman. n.d. "Pembuatan Mikrokristalin Selulosa Rotan Manau (Calamus Manan Sp.), Serta Karakteristiknya.," no. 2: 89-96.

Sumarno, Dharsono, and N.R Ardi Chandra. 2020. "An Effort of Furniture Design Development through the Utilization of Rice Straw Gogo." In ICADECS International Conference on Art, Design, Education and Cultural Studies, 1:238-245. KnE Social Sciences. https://doi.org/10.18502/kss.v4i12.7600.

Zakikhani, Parnia, R Zahari, M T H Sultan, and D L Majid. n.d. "Extraction and Preparation of Bamboo FibreReinforced Composites" 63: 820-28. 
Zuraida, A., T. Maisarah, and W. M.Y. Wan-Shazlin-Maisarah. 2017. "Mechanical, Physical and Thermal Properties of Rattan Fibre-Based Binderless Board." Journal of Tropical Forest Science 29 (4): 485-92. https://doi.org/10.26525/jtfs2017.29.4.485492. 